\title{
Escherichia coli Antibody: A Screening Test for Immunodeficiency
}

\author{
A. D. B. WEBSTER, T. EFTER, G. L. ASHERSON
}

British Medical fournal, 1974, 3, 16-18

\section{Summary}

Six patients suffering from recurrent chest infections were found to lack antibodies to a pooled antigen obtained from six different serotypes of commensal Escherichia coli bacteria. All had normal serum IgG concentrations, but five subsequently benefited from regular gammaglobulin injections. We suggest that the absence of such $\mathbf{E}$. coli antibodies usually indicates a clinically significant defect in antibody production. This simple screening test is of use in the diagnosis of primary and secondary immunodeficiency disorders.

\section{Introduction}

Adequate screening tests in cases of suspected qualitative defects in humoral immunity are still unsatisfactory. Patients with quantitative defects in antibody synthesis (hypogammaglobulinaemia) are easily diagnosed by routine immunoglobulin class estimations. Measurement of isohaemagglutinin titres may help in assessing IgM function but are not applicable to patients with blood group AB. Antibody titres to "common" antigens-for example, streptolysin $O$, measles, tetanus, diphtheria-are variable in normal healthy persons and measuring them is of limited value. We assessed the value of measuring Escherichia coli antibodies in patients with suspected immunodeficiency disease by comparison with a normal adult population and a number of patients with hypogammaglobulinaemia. Natural antibodies to the $\mathbf{O}$ antigen of commensal $E$. coli spontaneously occur in the serum of all normal children and remain throughout adult life (Kunin, 1962). These antibodies are presumably stimulated by $E$. coli bacteria in the gut. The specificity of antibody response probably depends upon previous exposure to specific serotypes and consequently will vary according to geographical location.

\section{Methods}

\section{SUBJECTS}

The patients all suffered from recurrent upper and lower respiratory tract infections and were divided into three groups.

Group 1 consisted of 15 patients aged 6-58 years (mean 24 years) whose IgG levels were $<300 \mathrm{mg} / 100 \mathrm{ml}$. Their hypogammaglobulinaemia affected all three main immunoglobulin classes. Their mean immunoglobulin values were: IgG 118 $\mathrm{mg} / 100 \mathrm{ml}$, IgA $2 \mathrm{mg} / 100 \mathrm{ml}$, IgM $24 \mathrm{mg} / 100 \mathrm{ml}$. Eight patients had developed symptoms in childhood and 7 had adult onset disease. Five patients were receiving weekly gammaglobulin injections.

Division of Immunology, Clinical Research Centre, Harrow, MiddleSex HA1 3UJ

A. D. B. WEBSTER, M.R.C.P., Senior Medical Registrar

T. EFTER, Research Assistant

G. L. ASHERSON, F.R.C.P., Consultant Physician

Group 2 consisted of 18 patients aged 6-62 years (mean 29 years) with moderate hypogammaglobulinaemia. Their IgG ranged from $300-500 \mathrm{mg} / 100 \mathrm{ml}$. Their mean immunoglobulin values were: IgG $351 \mathrm{mg} / 100 \mathrm{ml}, \operatorname{IgA} 17 \mathrm{mg} / 100 \mathrm{ml}$, IgM $47 \mathrm{mg} / 100 \mathrm{ml}$. Eight patients had developed symptoms in childhood, and 10 had adult onset disease. Twelve patients were receiving gammaglobulin injections.

Group 3 consisted of 24 patients aged 5-64 years (mean 31 years) with recurrent chest infections and IgG levels of $>$ $500 \mathrm{mg} / 100 \mathrm{ml}$. Mean immunoglobulin levels were: IgG $987 \mathrm{mg} / 100 \mathrm{ml}$, IgA $195 \mathrm{mg} / 100 \mathrm{ml}$, IgM $82 \mathrm{mg} / 100 \mathrm{ml}$.

The control group consisted of 38 normal adults aged 20-50 years. Their mean immunoglobulin values were: IgG $817 \mathrm{mg} /$ $100 \mathrm{ml}, \operatorname{IgA} 125 \mathrm{mg} / 100 \mathrm{ml}, \mathrm{IgM} 148 \mathrm{mg} / 100 \mathrm{ml}$.

Immunoglobulin IgG, IgM, and IgA measurements were performed using a modified Mancini method. The results were expressed as $\mathrm{mg} / 100 \mathrm{ml}$ of serum after conversion from international units (Rowe et al., 1972). Our normal adult mean ( \pm S.D.) laboratory values are as follows: IgG $980 \pm$ $227 \mathrm{mg} / 100 \mathrm{ml}$, IgA $200 \pm 133 \mathrm{mg} / 100 \mathrm{ml}$, IgM $115 \pm 58$ $\mathrm{mg} / 100 \mathrm{ml}$.

\section{PREPARATION OF E. COLI ANTIGEN}

The method of Anderson (1967) was followed. Six serotypes of $E$. coli which are commonly found in England were supplied by the Public Health Laboratory, Colindale. The types were as follows: 01.K1.H7., 02.K1.H4., 04.K3.H5., 06.K2ac. H1., 015.K14.H4., 075.K?H.5 They were grown on nutrient agar and then suspended in saline at is soncentration of 1,200 million organisms $/ \mathrm{ml}$. The suspension was boiled for two hours and then centrifuged for 30 minutes at $5,000 \mathrm{~g}$. The supernatants from each serotype were pooled, aliquoted, and stored at $-20^{\circ} \mathrm{C}$ until use.

\section{HAEMAGGLUTINATION TECHNIQUE}

Human group $O$ red cells were washed three times in saline. $0.1 \mathrm{ml}$ of packed washed red cells were added to $5 \mathrm{ml}$ of antigen solution and incubated at $37^{\circ} \mathrm{C}$ for $30 \mathrm{~min}$. The red cells were then washed three times in saline and adjusted to a $1 \%$ solution in saline. The serum under test was inactivated at $56^{\circ} \mathrm{C}$ for 30 minutes and divided into two $0.1 \mathrm{ml}$ aliquots. These were treated with $0.1 \mathrm{ml} \mathrm{M} / 15$ phosphate buffered saline pH. 7.3 or $0.1 \mathrm{ml} \mathrm{M} / 15$ phosphate buffered saline containing $.0 \cdot 1 \mathrm{~mol} / 1$ of 2-mercaptoethanol and incubated at $37^{\circ} \mathrm{C}$ for 30 minutes. Twofold dilutions of the serum $(25 \mu \mathrm{l})$ were then made in a microtitre tray and $25 \mu \mathrm{l}$ of antigen coated red cells added. The tray was incubated for three hours at $37^{\circ} \mathrm{C}$ and then left overnight at $4^{\circ} \mathrm{C}$ before reading.

\section{Results}

All 38 normal adults had an antibody titre $\geqslant 1 / 64$ (see fig.). In 24 of these the antibody seemed to be entirely of the IgM class-that is, mercaptoethanol sensitive. No significant titre of antibody was found in patients with severe hypogammaglobulinaemia (group 1). Most of the 24 patients with recur- 
Results of Laboratory Investigations in Six Patients without Antibody to E. Coli

\begin{tabular}{|c|c|c|c|c|c|c|c|c|c|c|c|c|c|c|c|c|}
\hline \multirow{4}{*}{$\begin{array}{l}\text { Case } \\
\text { No. }\end{array}$} & \multirow{4}{*}{$\begin{array}{c}\text { Age } \\
\text { (Years) }\end{array}$} & \multirow{2}{*}{\multicolumn{3}{|c|}{$\underset{\text { Immunoglobulins }}{\text { Serum }}$}} & \multicolumn{7}{|c|}{ Common Antibodies } & \multirow{4}{*}{$\begin{array}{l}\text { Response to } \\
\text { Immunization }\end{array}$} & \multirow{2}{*}{\multicolumn{4}{|c|}{$\frac{\text { Cellular Immunity }}{\text { ayed Hypersensitivity Skin Tests }}$}} \\
\hline & & & & & \multirow{3}{*}{$\begin{array}{l}\text { A.S.O. } \\
\text { Titre } \\
(\mathbf{U} / \mathrm{ml})\end{array}$} & \multirow{2}{*}{\multicolumn{2}{|c|}{$\begin{array}{l}\text { Isohaema- } \\
\text { gglutinins }\end{array}$}} & \multirow{2}{*}{\multicolumn{4}{|c|}{ Complement Fixing }} & & & & & \\
\hline & & & & & & & & & & & & & & & & \\
\hline & & IgG & IgA & IgM & & Anti-A & Anti-B & Measles & Mumps & $\begin{array}{l}\text { Herpes } \\
\text { Simplex }\end{array}$ & $\begin{array}{c}\text { Varicella } \\
\text { Zoster }\end{array}$ & & DNCB & Candida & P.P.D. & $\begin{array}{l}\text { PHA } \\
\text { Lympho- } \\
\text { cyte } \\
\text { Transfor- } \\
\text { mation* }\end{array}$ \\
\hline 1 & 16 & 750 & 46 & 43 & $50-200$ & $1 / 4$ & $1 / 2$ & $<1 / 10$ & $<1 / 10$ & $<1 / 10$ & $<1 / 10$ & $\begin{array}{l}\text { Diptheria Neg. } \\
\text { Tetanus } 0.01\end{array}$ & Neg. & Neg. & Neg. & 5,134 \\
\hline 2 & 15 & 755 & 198 & 11 & $200-300$ & & $1 / 8$ & $1 / 10$ & $<1 / 10$ & $<1 / 10$ & $<1 / 10$ & $\begin{array}{l}\text { Age } 11 \text { no antibody } \\
\text { rise after herpes } \\
\text { zoster infection; } \\
\text { absence of germi- } \\
\text { nal follicles in } \\
\text { lymoh }\end{array}$ & Pos. & Neg. & Neg. & 7,755 \\
\hline 3 & 61 & 760 & 344 & 84 & $<50$ & $1 / 2$ & $1 / 1$ & $<1 / 10$ & $<1 / 10$ & $<1 / 10$ & $<1 / 10$ & $\begin{array}{l}\text { TAB neg. } \\
\text { pneumococcal } \\
\text { polysaccharide } \\
\text { neg. }\end{array}$ & Pos. & Pos. & Neg. & 12,684 \\
\hline $\begin{array}{l}4 \\
5\end{array}$ & $\begin{array}{l}64 \\
19\end{array}$ & $\begin{array}{l}650 \\
840\end{array}$ & $\begin{array}{l}17 \\
88\end{array}$ & $\begin{array}{r}5 \\
760\end{array}$ & $\begin{array}{c}50-200 \\
<50\end{array}$ & $\begin{array}{r}\text { Trace } \\
1 / 16\end{array}$ & $\underset{1 / 4}{\text { Trace }}$ & $\begin{array}{l}<1 / 10 \\
<1 / 10\end{array}$ & $\begin{array}{r}<1 / 10 \\
1 / 10\end{array}$ & $\begin{array}{l}<1 / 10 \\
<1 / 10\end{array}$ & $\begin{array}{r}<1 / 10 \\
1 / 40\end{array}$ & $\begin{array}{l}\text { TAB neg. } \\
\text { Pneumococcal } \\
\text { polysaccharide }\end{array}$ & Neg. & $\begin{array}{l}\text { Not } \\
\text { Pos. }\end{array}$ & sted- & $\overrightarrow{2,926}$ \\
\hline 6 & 44 & 500 & 0 & 8 & $<50$ & & Trace & $<1 / 10$ & $<1 / 10$ & $<1 / 10$ & $<1 / 10$ & $\begin{array}{l}\text { neg. } \\
\text { Salmonella typhi } \\
\text { H } 1 / 4 \text { Salmonella } \\
\text { typhi AH No } 1: 2 \\
\text { rise after TAB }\end{array}$ & Pos. & Pos. & Neg. & 16,684 \\
\hline
\end{tabular}

A.S.O. = Antistreptolysin O. DNCB = Dinitrochlorobenzene. P.P.D. = Purified protein derivative of tuberculin. PHA. = Phytohaemagglutinin.
M Mean normal $( \pm$ S.D. $15,100 \pm 2,359$.

rent chest infections and normal serum concentrations of IgG (group 3) had normal $E$. coli antibody titres-that is $\geqslant 1 / 64$ Six patients, however, lacked antibody to $E$. Coli and the results of their laboratory investigations are analysed in greater detail in the table. Some clinical notes on these patients follow:

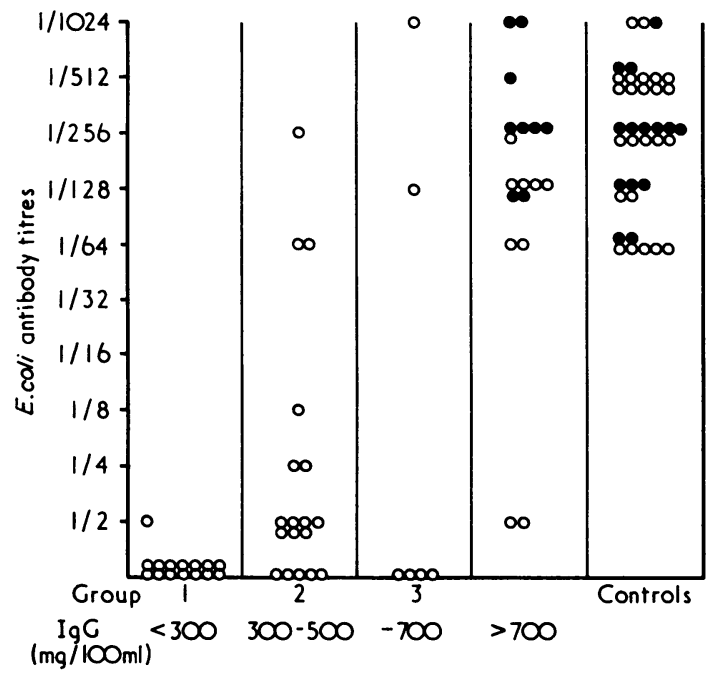

Relation between $E$. Coli antibody titres and serum IgG concentrations in 95 subjects. $\mathrm{O}=$ Titres fell below $1 / 8$ after mercaptoethanol. $O=$ Titres were $>1 / 8$ after mercaptoethanol.

Case 1.-This 20-year-old man had recurrent thrombotic microangiopathy involving kidneys and central nervous system when he was aged 13-15 years. He had a prolonged episode of bronchitis when he was 16 and two episodes of pneumonia (Haemophilus influenzae and pneumococcal) when aged 17-18 years. He has been given gammaglobulin treatment for three months and remains well. The serum IgG has subsequently fallen to sub-normal levels.

Case 2.- This 16-year-old boy had $H$. influenzae meningitis, febrile convulsions, two episodes of pneumonia, and severe herples zoster in childhood. He suffered from about five attacks of upper and lower respiratory tract infection each year in his teens. Regular garmmaglobulin injections began when he was 15 after pneumonia. Subsequently he had no time off school and suffered from only two mild winter colds. He has had gammaglobulin injections for 16 months.

Case 3.-When she was 63 this 68 -year-old woman had diarrhoea, chronic bronchitis, and weight loss, after which an encapsulated thymoma was removed. Subsequently there was a gradual deterioration in her chest symptoms with a chronic productive cough. She began gammaglobulin injections when she was aged 66, which resulted in the disappearance of all symptoms within three months. Serum IgG subsequently fell to subnormal levels. She has had gammaglobulin injections for 14 months and remains well.

Case 4.-For the previous 29 years this 64-year-old woman had winter bronchitis progressing to chronic productive cough at the age of 62. Chronic lymphatic leukaemia was diagnosed when she was 60 . At 63 years she was suffering from repeated episodes of severe chest infection and was semi-bedridden. Gammaglobulin injections were begun in August 1971 and her general health and cough improved. She became able to do housework and had only one episode of severe chest infection during the following year.

Case 5.-This 19-year-old man had recurrent chest infections in childhood. Suspected glandular fever when he was 10 was followed by persistent splenomegaly and recurrent lymphadenopathy. Splenectomy for thrombocytopenia was performed when he was 12 . He suffered from bronchitis, otitis media, and intestinal giardiasis in his early teens. When he was 15 he suffered from pyrexial episodes with leucopenia and thrombocytopenia, which were responsive to steroids. He remains on a maintenance dose of steroids.

Case 6.-This 44-year-ald man developed recurrent chest infections when he was 31 years, necessitating leave from work every three months. He had a perianal abscess when he was 42. Between October and December of 1972 he needed five courses of antibiotics for sore throat and malaise. He began gammaglobulin injections in January 1973 and has suffered no further illnesses.

\section{Discussion}

These results indicate that measurement of antibody to pooled $E$. coli antigen is a useful screening test for impaired antibody production. The decision to use pooled antigen resulted from the observation that about $25 \%$ of normal subjects had titres below $1 / 4$ when tested separately against serotypes $02 . \mathrm{K}_{1} . \mathrm{H} 4$ and $075 . \mathrm{K}^{2} \mathrm{H}$. Virtually all normal subjects over the age of two years, however, have titres to the pooled antigen of $>$ $1 / 64$.

Antibodies to pooled antigen were absent in patients with severe hypogammaglobulinaemia (group 1) and in most cases of moderate hypogammaglobulinaemia (group 2). They were 
absent in six out of 24 patients who presented with recurrent chest infections but who had normal serum IgG immunoglobulin levels. Three had normal levels of IgG or IgM or both, but three had depression of serum IgM. One patient was suffering from chronic lymphatic leukaemia. Five of these patients were subsequently treated with gammaglobulin injections which resulted in a reduction in the frequency of their infections. IgG levels in three patients subsequently fell to subnormal levels, suggesting that the absence of $E$. coli antibody occurred before a quantitative immunoglobulin deficiency.

About $70 \%$ of normal subjects have haemagglutinating $E$. coli antibody which is destroyed by mercaptoethanol. This finding supports previous contentions (Michael and Rosen, 1963) that much of the serum antibody against Gram-negative organisms is of the IgM type. It is not possible, however, to make any statements about the quantity of IgG antibody present since haemagglutinating techniques favour the recognition of IgM. Nevertheless, about $30 \%$ of normal adults have haemagglutinating antibody of the $7 \mathrm{~S}$ variety (mercaptoethanol resistant). This is likely to be IgG antibody, which is in keeping with the observations of Cohen and Norins (1968). The common occurrence of IgG antibodies to $E$. coli probably explains why we found no correlation between the level of serum IgM and the titre of $E$. coli antibody or between the titre of isohaemagglutinins and $E$. coli antibody in patients studied. Despite the absence of $\boldsymbol{E}$. coli antibodies in most of the patients with hypogammaglobulinaemia there were no cases of lower or upper urinary tract infection. It is exceptional for such patients to suffer from any infective complica- tion of the urinary tract, and in our wider series of about $\mathbf{7 0}$ patients (18 females) there was only one case of recurrent cystitis and this was associated with a sterile pyuria.

It is possible that a defect in the production of $E$. coli antibody may be due to a specific defect in the response to polysaccharide antigens. Work with mice has shown that some of these responses are independent of thymic processed $\mathbf{T}$ cells (Baker et al., 1970). For this reason, the presence of $E$. coli antibodies does not rule out the possibility of a clinically significant and treatable defect in the antibody response to protein antigens. Assessment of responses after immunization with antigens such as pneumococcal polysaccharide and haemocyanin may show such a dichotomy.

We thank Jill Boler, Margaret Kinsley, Margaret North, Lillian Racine, Stuart Line, and the technicians of our blood transfusion laboratory for their excellent help. We are also most grateful to Dr. B. Rowe, Salmonella and Shigella Reference Laboratory, Colindale, for supplying the $E$. coli serotypes and to the physicians who allowed us to study their patients.

\section{References}

Kunin, C. M. (1962). Archives of Internal Medicine, 110, 182

Rowe, D. S., Grab, B., and Anderson, S. G. (1972). Bulletin of the World Health Organization, 46, 67.

Andersen, H. J. (1967). Acta Paediatrica Scandinavica, 56, 637

Michael, J. G., and Rosen, F. S. (1963). Fournal of Experimental Medicine,

118, 619.
Cohen, I. R., and Norins, L. C. (1968). Fournal of Clinical Investigation, 47, 1053.

Baker, P. J., et al. (1970). fournal of Immunology, 105, 1581.

\title{
Linoleate and Fatty-acid Patterns of Serum Lipids in Multiple Sclerosis and Other Diseases
}

\author{
W. CLAYTON LOVE, A. CASHELL, M. REYNOLDS, NOEL CALLAGHAN
}

British Medical fournal, 1974, 3, 18-21

\section{Summary}

The linoleic acid content of serum lipids was measured in 47 patients with multiple sclerosis, 29 patients with other neurological diseases, 35 patients with acute non-neurological illnesses, and 49 healthy control subjects. Reduced linoleic acid content of serum lipids was not specific to multiple sclerosis and occurred in all ill patients with acute non-neurological illness. The fatty-acid pattern of serum lipids in illness resembles that of essential fattyacid deficiency. It seems that this pattern of reduced linoleic acid content with increased oleic, palmitic, and palmitoleic acid content may be a general phenomenon in ill patients.

Clinical Biochemistry Laboratory, Trinity College, Dublin, Ireland W. CLAYTON LOVE, M.SC., PH.D., Senior Lecturer in Clinical Biochemistry

Department of Neurology, St. Finbarr's Hospital, Cork, Ireland A. CASHELL, B.SC., Research Assistant

M. REYNOLDS, B.sC., Research Assistant

NOEL CALLAGHAN, M.D., F.R.C.P., Consultant Neurologist

\section{Introduction}

The linoleic acid content of serum lipids is decreased in multiple sclerosis (Baker et al., 1964; Tichy et al., 1969). The cholesterol ester fraction shows the greatest decrease in linoleate content (Baker et al., 1965). Moreover, the decreased linoleate fraction is not peculiar to plasma lipids but also occurs in lipids of red cells and platelets (Gul et al., 1970). Previous work established that the fatty-acid composition of phosphatidylcholines (lecithins) from the brains of patients with multiple sclerosis differed from that of normal brain (Baker et al., 1963). Even in non-plaque areas saturated fatty acids increased relative to unsaturated fatty acids. Several other reports have shown changes in relative proportions of saturated and unsaturated fatty acids in brains of multiple sclerosis patients (Gerstel et al., 1961 ; Cumings et al., 1965; Arnetoli et al., 1969; Clausen and Hanson, 1970; Gerstel et al., 1970; Alling et al., 1971).

Previous studies compared linoleic acid composition of serum lipids in multiple sclerosis with levels in subjects with other neurological disorders and in healthy subjects (Baker et al., 1964; Belin et al., 1971). No comparison seems to have been made with diseases which did not have a neurological basis. We considered that it was essential to examine linoleic acid levels of serum lipids in non-neurological diseases before coming to a definite conclusion about the significance of altered linoleic acid levels in multiple sclerosis.

We therefore set out to compare the levels of serum linoleic acid in multiple sclerosis with levels found in acute hospital 